\title{
IMPROVING PRE-SALT RESERVOIRS SEISMIC IMAGES WHEN CONSIDERING THE STRATIFIED EVAPORITES INSERTION IN THE INITIAL MODEL FOR THE VELOCITY UPDATING PROCESSES PRIOR TO THE SEISMIC MIGRATION
}

\author{
Alexandre Rodrigo Maul1,2, Marco Antonio Cetale Santos², Cleverson Guizan Silva², \\ Leonardo Márcio Teixeira da Silva ${ }^{1,2}$, María de Los Ángeles González Farias ${ }^{3}$, Josué Sá da Fonseca ${ }^{1}$, \\ Roberto de Melo Dias ${ }^{1}$, João Batista Teixeira Boechat ${ }^{1}$, Filipe Augusto de Souto Borges ${ }^{1}$, \\ Lívia Falcão Fernandes ${ }^{1}$, Thiago Martins Yamamoto ${ }^{1,2}$ and Rodrigo Leandro Bastos Pontes ${ }^{1,2}$
}

\begin{abstract}
Structurally complex areas, such as the pre-salt section in the offshore Santos Basin, SE Brazil, are challenging to represent geologically using seismic images. One of the main causes of the observed imaging problems is the evaporitic section and its considerations about velocities used for seismic migration purposes. Some authors consider set to this section an almost constant value (close to $4,500 \mathrm{~m} / \mathrm{s}$ ) which approximately represents the halite velocity, the most abundant mineral in this salt formation. Others, over these models, apply the tomographic inversion or FWI schemes giving to the velocity model the mathematical support to build confident seismic images. We believe in the importance of building starting velocity models reflecting the existing geological features prior to applying the tomographic/FWI updating. In this sense, we propose the insertion of the so-called stratifications within the evaporitic section using an adaptation of the model-based seismic inversion technique. Following this new velocity model including the stratification, we suggest tomographic iterations update or FWI, to add to the geological constrains of the model the needed mathematical convergence. Finally, in this work, we performed the seismic migration with and without inserting these geological features in the initial velocity model and compared the results.
\end{abstract}

Keywords: evaporitic section, stratifications, velocity model, seismic migration, seismic image.

RESUMO. Em áreas estruturalmente complexas, como na seção pré-sal da Bacia offshore de Santos, região SE do Brasil, é um desafio representar a geologia utilizando imagens sísmicas. Uma das principais causas dos problemas observados está nas considerações sobre a seção evaporítica e suas velocidades com propósito de migração sísmica. Alguns autores consideram esta seção como tendo velocidades geralmente constantes (próximas de $4.500 \mathrm{~m} / \mathrm{s}$ ), o que representa aproximadamente 0 comportamento da halita, o mineral mais abundante nesta seção. Outros, sobre este modelo, aplicam a atualização por inversão tomográfica ou FWI para dar ao modelo de velocidades o suporte matemático necessário para construir imagens sísmicas confiáveis. Nós acreditamos na importância de construir modelos iniciais de velocidades que reflitam as características geológicas existentes antes de aplicar esta atualização tomográfica/FWI mencionada. Neste sentido, propomos a inserção das denominadas estratificações dentro da seção evaporítica, utilizando uma adaptação da técnica de inversão sísmica model-based. Seguindo este novo modelo incluindo as estratificações, sugerimos a atualização por iterações tomográficas ou FWI, para adicionar ao controle geológico do modelo a convergência matemática necessária. Finalmente, neste trabalho, nós realizamos a migração com e sem a inserção destas características geológicas no modelo inicial de velocidades e comparamos os resultados.

Palavras-chave: seção evaporítica, estratificações, modelo de velocidade, migração sísmica, imagem sísmica.

\footnotetext{
${ }^{1}$ Petrobras - Reservoir Geophysics, Avenida Henrique Valadares, 28 / 6 andar, 20031-030, Rio de Janeiro, RJ, Brazil - E-mails: alexandre.maul@petrobras.com.br, Imtsilva@petrobras.com.br, josuefonseca@petrobras.com.br, roberto.dias@petrobras.com.br, jboechat@petrobras.com.br, filipeborges@petrobras.com.br, liviafalcao@petrobras.com.br, thiagomyamamoto@petrobras.com.br, rpontes@petrobras.com.br

${ }^{2}$ Universidade Federal Fluminense - UFF, Geology and Geophysics, Av. Milton Tavares de Souza, s/nº - Gragoatá, 24210-340, Niterói, RJ, Brazil - E-mails: marcocetale@id.uff.br, cguizan@id.uff.br

3Emerson Automation Solutions, Av. Rio Branco, 138, sala 1702, 20040-002, Rio de Janeiro, RJ, Brazil - E-mail: maria.g.gonzalez@emerson.com
} 


\section{INTRODUCTION}

Drilling in the Brazilian offshore pre-salt reservoirs, in the Santos Basin, always requires crossing an evaporitic section that ranges from dozens of meters to a few kilometers of salt thickness. Besides, the presence of different types of evaporitic minerals, with diverse mechanical behaviors, imposes the creation of structural complex scenarios. Therefore, understanding and properly characterizing the rocks inside this section are essential for diverse activities as safety during the well drilling operations, geomechanical hazard evaluations, and geological velocity modeling for seismic processing, among many others processes.

Ji et al. (2011) defend the idea that homogenous velocity for the evaporitic section affects the images quality under the salt section. They cite the weakness and discontinuity in seismic reflection, diffractions-like events and misinterpretation as the main problems when choosing those homogeneous compressional velocity models over more heterogeneous ones. They propose the insertion of heterogeneities inside the evaporitic section, to better represent the compressional velocity variations.

Huang et al. (2010), evaluating seismic images in the Santos Basin, consider that good images for the pre-salt reservoir do not ensure a reliable depth position for the base of salt, which is the reference for the top of pre-salt reservoir. They associate this phenomenon with the usage of simple velocity models in the evaporitic section. These models disregard the velocity inhomogeneity as they are noticed by the stratifications inside the evaporitic section. They also confirm the necessity to adopt a complete "salt model" to correctly position the reservoir structures.

Jones \& Davison (2014) mention many difficulties for the seismic imaging around or inside the salt bodies and use a dataset of the Santos Basin as the main example to emphasize those difficulties. They cite the inaccuracies in the compressional velocity assumptions or representations for the evaporitic section velocity model as the probable cause of this issue. They also observe some features such as interbedded layers (stratifications), overlying layers (a superior anhydrite and/or the Albian rafts presence) and salt flanks (encompassed within the HSD - Hidden Stratified Domain as proposed by Maul et al., 2018b).

Jackson et al. (2015) emphasize the presence of "enigmatic structures" within the evaporitic section in the Santos Basin. In Mohriak et al. (2008), we found the first statement of the term "enigmatic reflectors" which we believe have same meaning of the "enigmatic structures" as mentioned by Jackson et al. (2015).
These features probably are the part of the seismic response of interbedded layers as mentioned by Jones \& Davison (2014).

Since 2015, several results related to the evaporitic stratification modeling intending to enhance the pre-salt projects have been presented (Maul et al., 2015; Jardim et al., 2015; Meneguim et al., 2015). Maul et al. (2018b) summarize and state these features as the evaporitic stratifications caused by the mineral variation.

During the methodology development, several applications have taken advantage of using this strategy of modeling evaporitic stratifications. The more promising applications are related to uncertainties (Maul et al., 2015; Jardim et al., 2015), geomechanics (Toríbio et al., 2017; Teixeira et al., 2018), Kirchhoff migration and Reverse Time Migration - RTM (Gobatto et al., 2016; Fonseca et al., 2018; Maul et al., 2018a) and the initial model for Least-Square Migration (Dias et al., 2019).

In seismic migration tasks, until the early 2000's, the evaporitic section in the Santos Basin was usually considered as almost constant (compressional velocity around 4,500 m/s), with some tomography approach in order to update the compressional velocity, observing the gather alignment behaviors. Falcão (2017) proves that a reasonable depth migration in complex areas such as the pre-salt reservoirs in the Santos Basin depends on the accuracy of the geological velocity models.

Although the tomographic inversion supports the entire migration process, it is not a perfect solution for the velocity models updating (Guo \& Fagin, 2002). These authors emphasize the necessity of incorporating a reasonable geological knowledge into velocity modeling workflow. Potentially, the FWI (Full-Waveform Inversion) methodology can generate high-resolution velocity models (Vigh \& Starr, 2008), which are currently appropriate for the RTM (Reverse Time Migration) technique. However, according to Vigh et al. (2009), one of the main challenges for the FWI techniques is to produce (or to reproduce) a good initial velocity model to generate the seismic images with geological confidence regarding the subsurface geology.

Currently, the state-of-the-art regarding processing techniques are FWI for velocity model building (Ben-Hadj-Ali et al., 2008; Barnes \& Charara, 2009; Operto et al., 2013; Vigh et al., 2014) and Least-Square Migration (LSM) for imaging as per discussed in Nemeth et al. (1999); Hu et al. (2001); Dias et al. (2017); Wang et al. (2017); Dias et al. (2018). These techniques are becoming the standard for the pre-salt projects in the Santos Basin, offshore Brazil. 
Even though laboratory measurements indicate that the anisotropy in core evaporite samples is negligible (Yan et al., 2016), the multilayered rock sequences impose extrinsic anisotropy behavior when the seismic wavelength is significantly larger than the thickness of any individual layers (Backus, 1962).

Raymer et al. $(1999,2000)$ state that the salt extrinsic anisotropy could be over than $7 \%$ in the preferred direction of evaporation. Landrø et al. (2011) analyze salt-mine outcrops and infer a moderate degree of anisotropy in the order of $5 \%$ difference between horizontal and vertical velocities. Several authors consider that anisotropy for any geological layer is mandatory in order to generate more realistic seismic images (Cogan et al., 2011; Zdraveva et al., 2011; Cooke et al., 2012).

The importance of the anisotropy for the seismic imaging process is undoubtable. However, this aspect is not within the scope of this work and further discussions about this matter are not presenting in our results.

\section{METHODOLOGY}

The first part of the methodology applied in this project follows the workflow presented in González et al. (2016), see Figure 1. This method allows the insertion of the salt stratifications or the layered sequence using seismic acoustic inversion (as presented by Meneguim et al., 2015), or any other seismic attribute if the inversion output is not available. The $1 \mathrm{D}$ analysis is performed with well logs and cutting supporting all stages. The first 3D approach is an initial model with geological constraints, where the stratifications are represented by combining velocities and seismic attributes. Then, a model-based inversion can be done for a better characterization of the rocks in the evaporitic section. Finally, a seismic facies classification, using impedance response in a Bayesian probabilistic approach, is performed to improve the modeling and to include uncertainty analysis to work with several scenarios. This gives to the evaporitic section the needed heterogeneity, especially to generate the initial compressional velocity model for the tomographic/FWI updating process, which precedes the migration as postulated by Fonseca et al. (2018), see Figure 2. The workflow requires previous stratigraphic interpretation, rock-physics analysis, model-based seismic inversion building and conversion from acoustic impedance to compressional velocity. It provides the initial velocity model to velocity updating (Tomography/FWI). After those velocity updating processes, and the gather alignment evaluation, another seismic migration is performed, generating a new and enhanced seismic image.

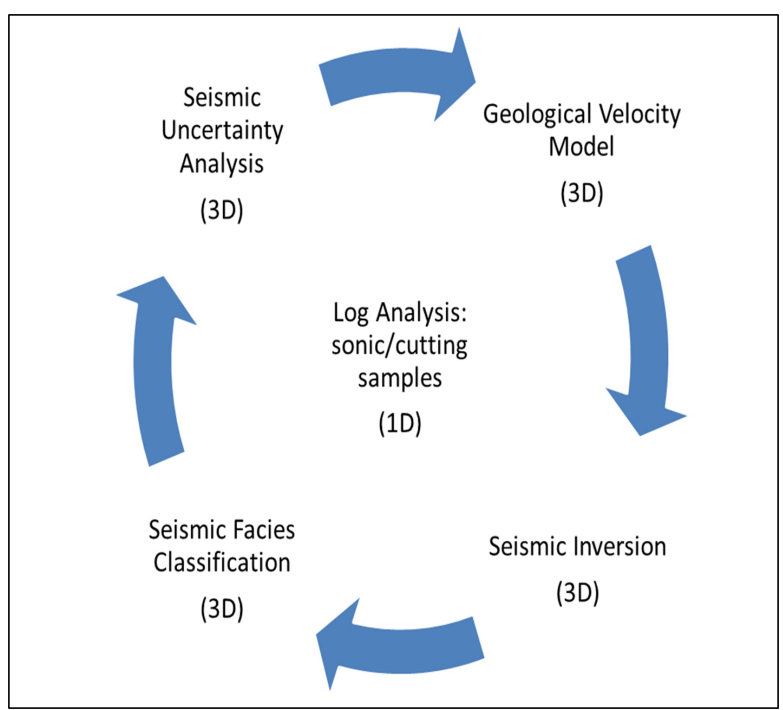

Figure 1 - Proposed workflow to generate a more realistic geological seismic velocity model (adapted from González et al., 2016).

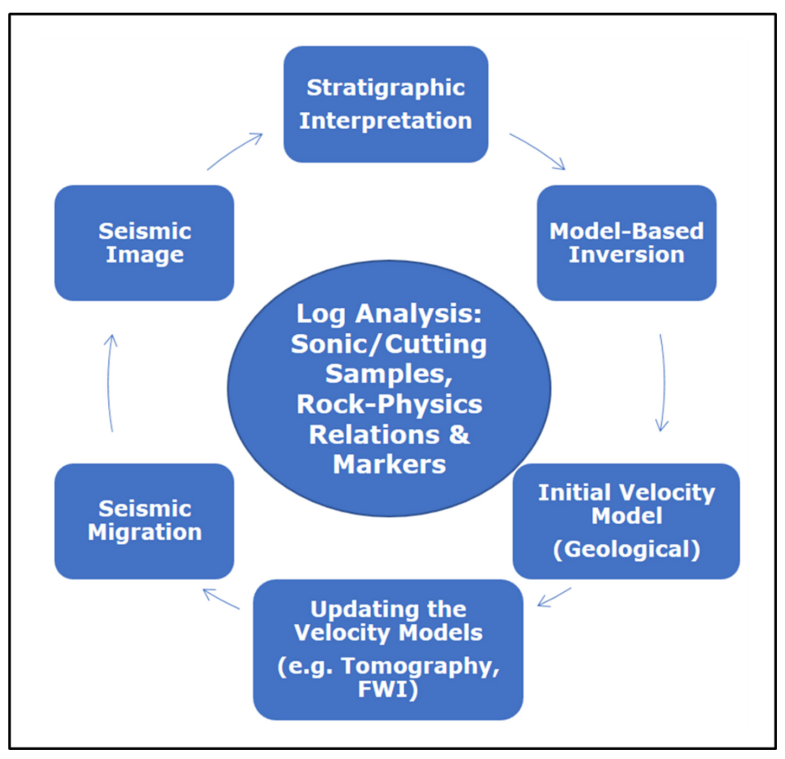

Figure 2 - Proposed workflow for the seismic image updating (adapted from Fonseca et al., 2018).

To verify the efficiency of the methodology, we performed the tomographic inversion process and analyzed the gather alignment panels over two models. The first model is the standard one, which considers an almost constant compressional velocity model for the evaporitic section; the second is the stratified one, generated by an acoustic seismic inversion, as tested and presented in Gobatto et al. (2016); Fonseca et al. (2017); Fonseca et al. (2018); Maul et al. (2018a). 


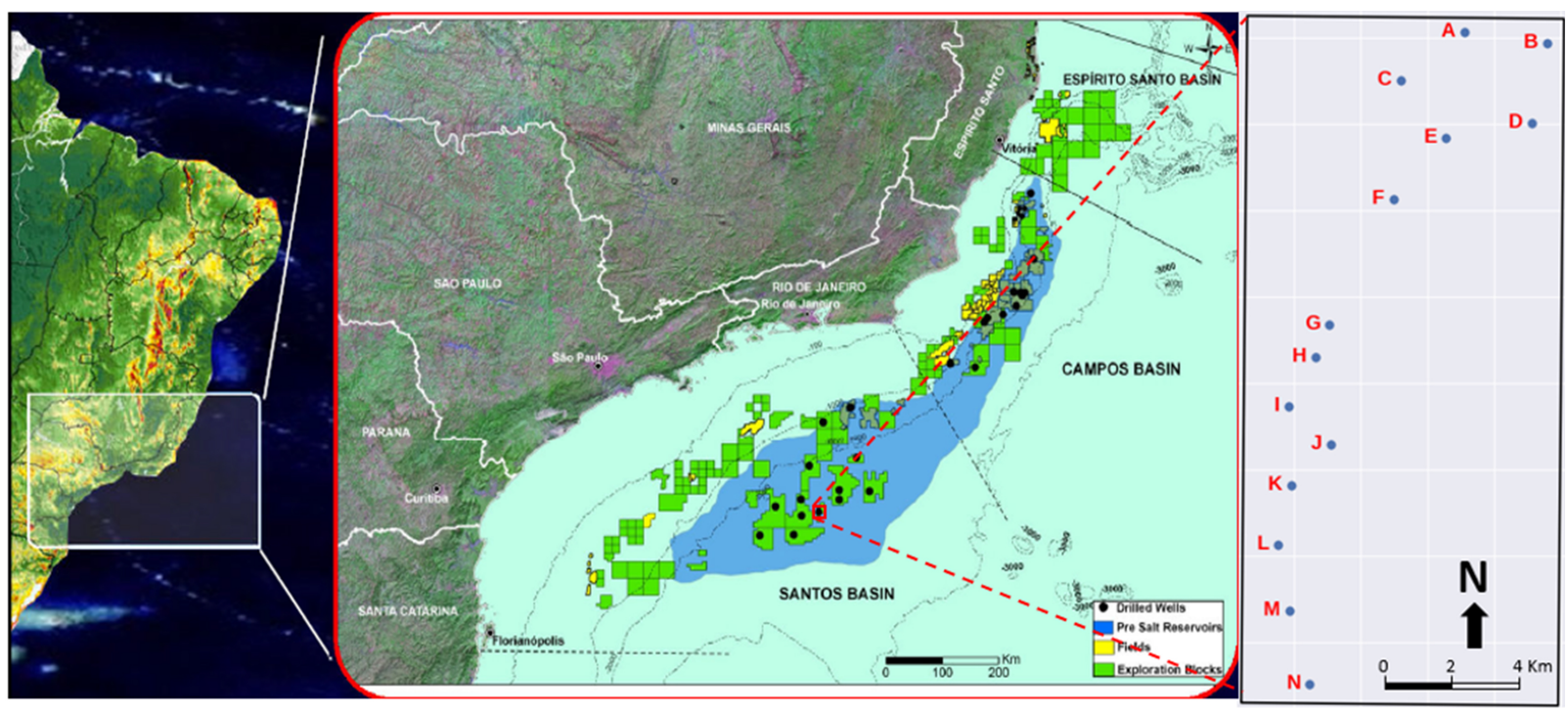

Figure 3 - Location of study area (regional) and details of the available data. Dark blue shading is the area with hydrocarbon occurrences in the pre-salt province in the Santos and Campos Basins, covering an area of approximately $350,000 \mathrm{~km}^{2}$. Water column ranges from 2,000 to $3,000 \mathrm{~m}$.

\section{STUDY AREA AND AVAILABLE DATA}

The study area is located in the pre-salt province in the Santos and Campos Basins. The specific tested dataset for this work is inserted into the project area that the first author has the formal authorization from the Agência Nacional do Petróleo, Gás Natural e Biocombustíveis (ANP) to develop his doctorate research. This area is a piece of the pre-salt Santos Basin province (Fig. 3) and contains a pre-stack depth migrated (PSDM) covering an area of approximately $200 \mathrm{~km}^{2}$ and 14 wells with a broad suite of logs. In this study, the wells were labeled with capital letters from A to N, and the official names can be found in Table 1. Maul et al. (2018a \& 2018c) demonstrate, using 182 wells of different 9 projects/fields in the Santos Basin, that the evaporitic section of these studied fields has many features in common, such as mineral percentages of occurrence, mineral percentages $x$ thickness relation and velocity ranges per mineral groups.

\section{RESULTS, ANALYSIS AND DISCUSSIONS}

The type variation of minerals, occurrence frequency and velocity are important considerations addressed when analyzing heterogeneities inside the evaporitic section. Figure 4 shows some wells drilled in the Santos Basin emphasizing the multilayered evaporite sequence. In this sense, Maul et al. (2018c) summarized the study of these 182 wells (Table 2), reflecting the average occurrence for each field, based on the following grouping: Low Velocity Salt (LVS); Halite and High Velocity Salt (HVS). The low velocity salt group (LVS) is mainly composed by carnallite, tachyhydrite, sylvite and other mobile salts; and the high velocity salt group (HVS) is basically composed by anhydrite and gypsum.

Table 1 - Correspondence between the well designations used in this study and the official names from ANP.

\begin{tabular}{cc}
\hline This Study & ANP \\
\hline A & 3-BRSA-788-SPS \\
B & 9-BRSA-1037-SPS \\
C & 8-SPH-23-SPS \\
D & 8-SPH-13-SPS \\
E & 7-SPH-14D-SPS \\
F & 7-SPH-8-SPS \\
G & 7-SPH-4D-SPS \\
H & 9-BRSA-928-SPS \\
I & 7-SPH-5-SPS \\
J & 9-BRSA-1043-SPS \\
K & 1-BRSA-594-SPS \\
L & 7-SPH-1-SPS \\
M & 7-SPH-2D-SPS \\
N & 3-BRSA-923A-SPS \\
\hline
\end{tabular}

Figure 5 illustrates how the compressional velocity varies among the minerals. In this study, we considered the average value per mineral plus the variation (+/-) taking two standard deviations as the reference. 


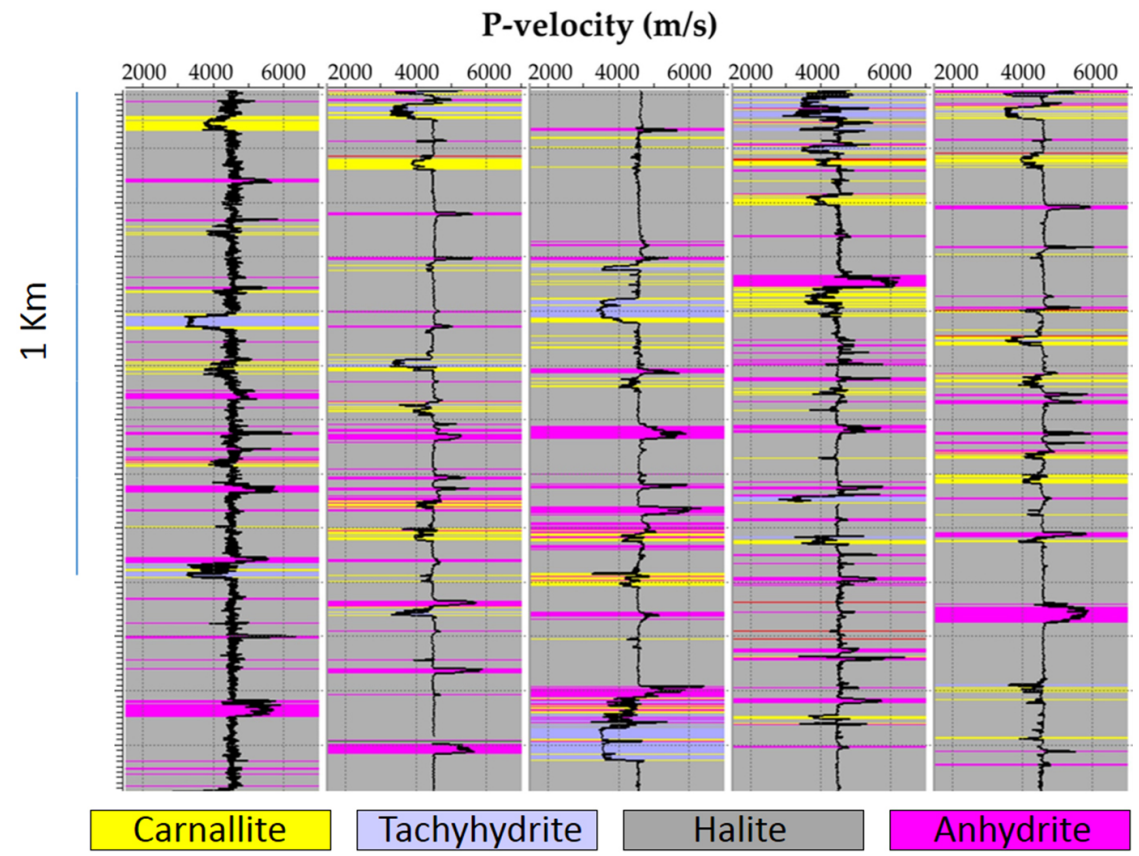

Figure 4 - Identified stratifications inside the evaporitic section, considering a small piece of wells (5) from the 182 previously mentioned. Adapted from Maul et al. (2018a).

Table 2 - Salt proportions and interval velocities (m/s) for nine fields inside the Santos Basin.

\begin{tabular}{ccccccccc}
\hline Field & \# Wells & \% LVS & LVS ACV & \% Halite & Halite ACV & \% HVS & HVS ACV & WCV \\
\hline 1 & 20 & 8 & $4,018.56$ & 83 & $4,480.88$ & 8 & $5,210.27$ & $4,462.56$ \\
2 & 29 & 9 & $4,218.47$ & 82 & $4,563.69$ & 9 & $4,975.84$ & $4,567.53$ \\
3 & 17 & 12 & $4,054.42$ & 77 & $4,498.25$ & 12 & $4,989.92$ & $4,505.66$ \\
4 & 3 & 13 & $3,971.00$ & 71 & $4,507.09$ & 16 & $4,927.59$ & $4,505.04$ \\
5 & 5 & 3 & $4,167.00$ & 84 & $4,538.00$ & 13 & $5,123.33$ & $4,576.00$ \\
6 & 7 & 3 & $4,264.19$ & 80 & $4,509.87$ & 17 & $5,061.36$ & $4,596.05$ \\
7 & 72 & 8 & $4,122.33$ & 81 & $4,526.47$ & 11 & $5,105.84$ & $4,560.03$ \\
8 & 25 & 4 & $4,182.53$ & 88 & $4,533.59$ & 8 & $5,003.35$ & $4,547.16$ \\
9 & 4 & 6 & $4,055.63$ & 81 & $4,486.58$ & 13 & $5,077.49$ & $4,535.67$ \\
\hline TNW & 182 & & & & & & & \\
\hline AVG & & 7 & $4,117.13$ & 81 & $4,516.05$ & 12 & $5,052.78$ & $4,539.52$ \\
\hline
\end{tabular}

LVS: Low Velocity Salt; HVS: High Velocity Salt; ACV: Average Compressional Velocity; WCV: Weighted Compressional Velocity; TNW: Total Number of Wells; AVG: Average; Compressional Velocity (m/s). Modified from Maul et al. (2018c).

In Figure 6, Fonseca et al. (2018), using 2 among the 182 available wells, illustrate how the mineral occurrence can be quantified per well, considering the mineral grouping proposed by Maul et al. (2018b), following the methodology described in
Amaral et al. (2015), which intends to fill the well-log gaps using the interpreted drill cutting samples. In the mentioned study, the authors calculated the average compressional velocity for each well location, weighting by each mineral grouping proportion. 


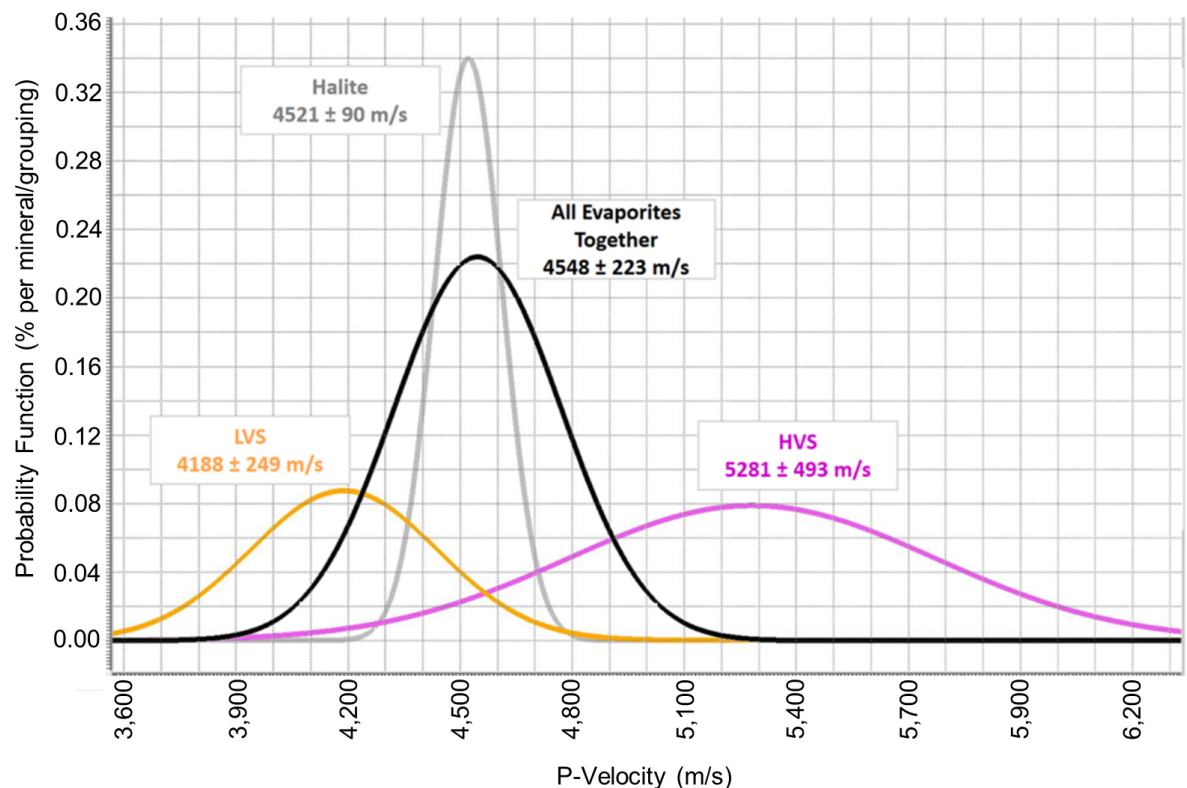

Figure 5 - Mineral compressional velocity variation obtained from the logs considering a sample of 10 wells, among the 182 ones summarized in Table 2. Adapted from Maul et al. (2018a).
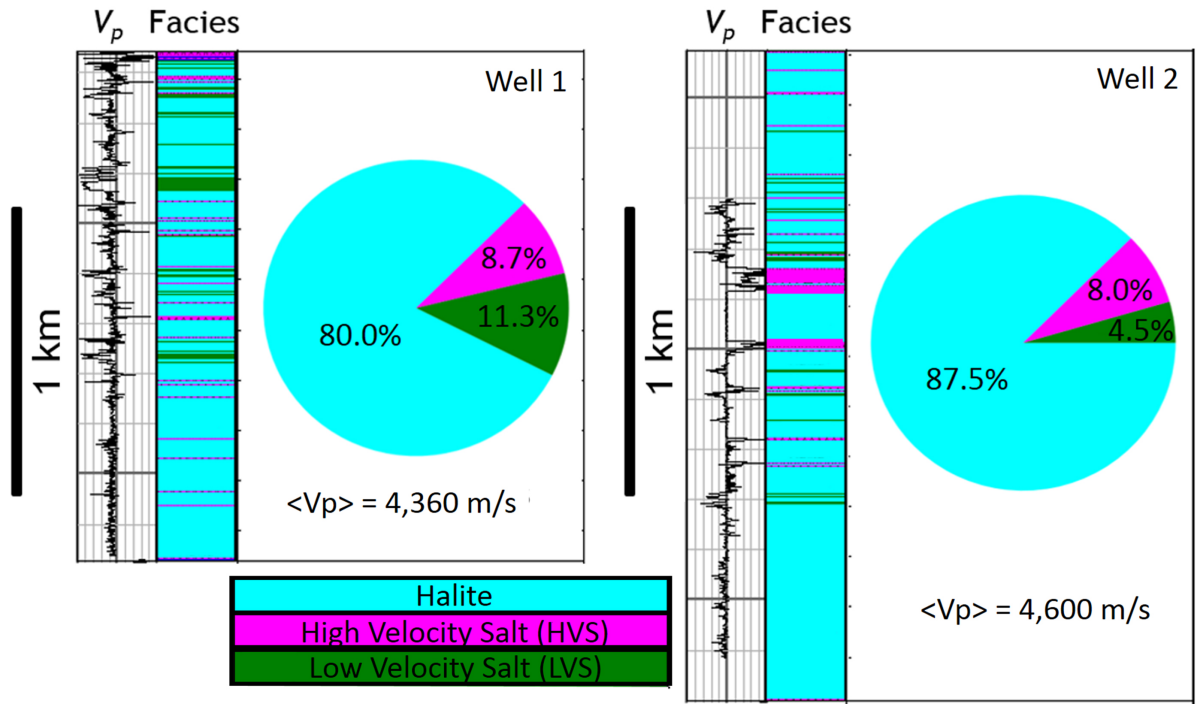

Figure 6 - Example of the mineral occurrence (grouping) of 2 wells from the 182 wells analyzed for the development of the methodology. Adapted from Fonseca et al. (2018).

Analyzing Figure 6, it is reasonable to infer that the mineral content would be influencing the average compressional velocity at any well location. At well 1 , the LVS proportion is higher than the HVS one. This difference affects the average compressional velocity in this well, decreasing its value. On the opposite way, analyzing well 2, the HVS content is higher than the LVS, increasing the average velocity compressional velocity. However, in both cases, the seismic velocity used for the legacy migration at those locations is close to $4,500 \mathrm{~m} / \mathrm{s}$, representing only the halite compressional velocity.

Figure 7 depicts the compressional velocity for the evaporitic section considering the stratification insertion by combining rock-physics and seismic inversion. We also compare it with the tomographic compressional velocity provided by 


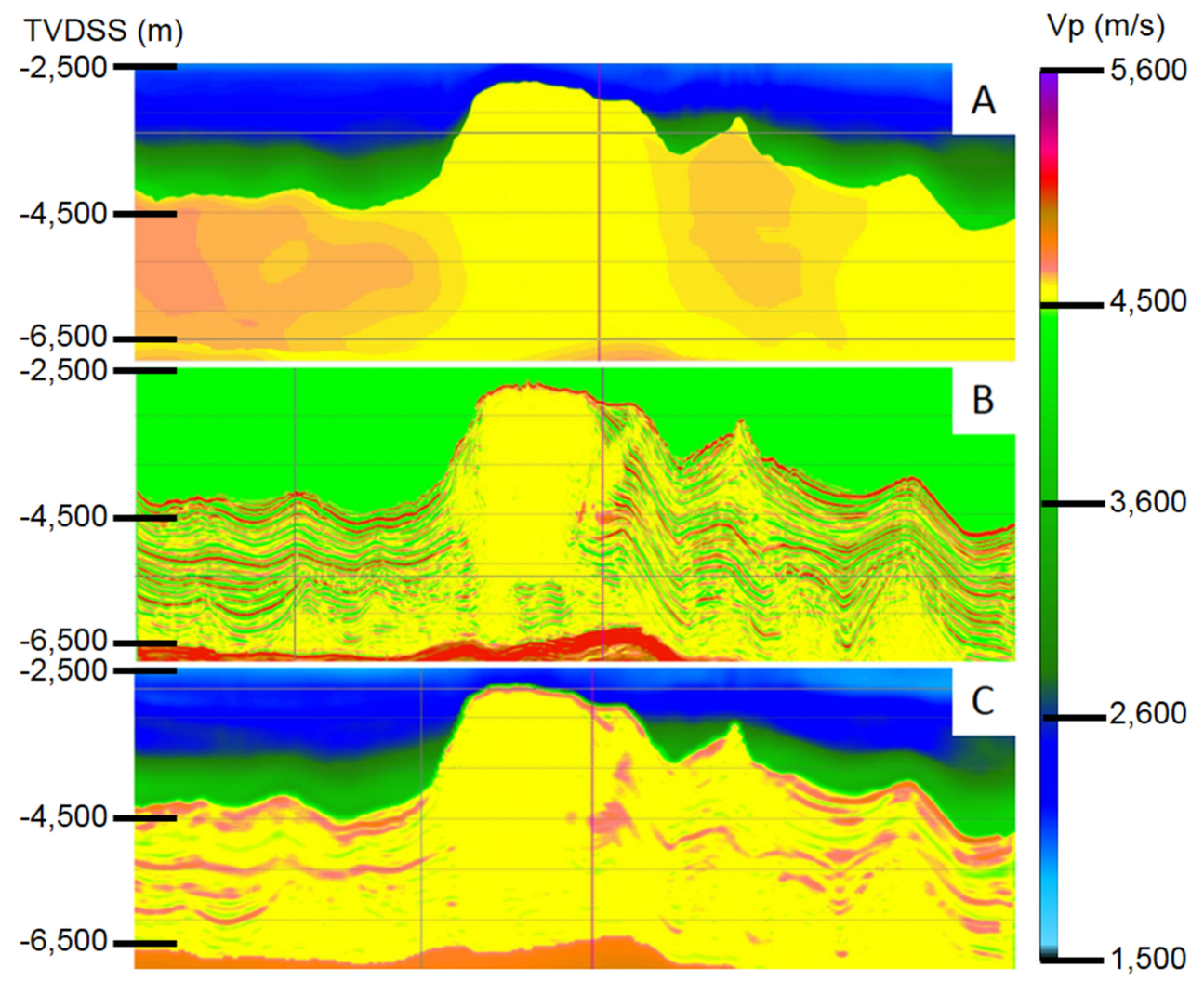

Figure 7 - Salt heterogeneity representation: A: Compressional velocity obtained from the inversion tomography. This model corrects the almost constant velocity model using gather alignment as criteria; B: Compressional velocity obtained from the acoustic inversion results (model-based approach) applying a polynomial transformation to the impedance guided by the well logs. It illustrates the existing stratification controlled by amplitude response and well information; C: Smoothed compressional velocity model obtained from the inversion results. In this case, after applying a polynomial transformation guided by the well logs, we smoothed the model vertically. Adapted from Maul et al. (2018a).

the seismic processing. It is important to notice that, in order to use the stratified model to migrate the data, a vertical smoothing is necessary (Fig. 7C). The importance of considering the model-based inversion approach to better establish the stratification is well exemplified and documented in several works (Meneguim et al., 2015; Teixeira et al., 2017; Toríbio et al., 2017; Barros et al., 2017, Fonseca et al., 2018; Teixeira et al., 2018; Maul et al., 2019a, 2019b; Teixeira \& Lupinacci, 2019).

As mentioned in Figure 7, the acoustic inversion output (Acoustic Impedance - Ip) must be converted to compressional velocity (Vp) to be used in the migration process. In this case, we consider the polynomial fit illustrated in Figure 8. It is important to mention that the curve-fitting choice is a source of uncertainties for the entire study. Thus, considerations about uncertainties are important in the development of similar studies. To emphasize this uncertainty estimation and the alternatives in controlling it,
Teixeira \& Lupinacci (2019) suggest the confidence level for the estimation as one possibility. In this case the authors regards the $95 \%$ of the best-fitting curve and propose that inside this confidence level any alternative fit are defensible. However, the physical implications in the choice of different equations need to be carefully analyzed and constrained by well logs, essentially because they can lead to incorrect depth positioning.

In Figure 9 we present two maps of the average compressional velocity for the evaporitic section. Figure $9 \mathrm{~A}$ illustrates the average compressional velocity map for the evaporitic section considering the original tomographic velocity model (the standard approach). In that case, the methodology applied a "flooded salt model" (initially almost constant - 4,500 $\mathrm{m} / \mathrm{s}$ ), followed by tomography - three iterations were necessary to achieve a good gather alignment. In the second map (Fig. 9B), we built the compressional velocity model for the evaporitic section 


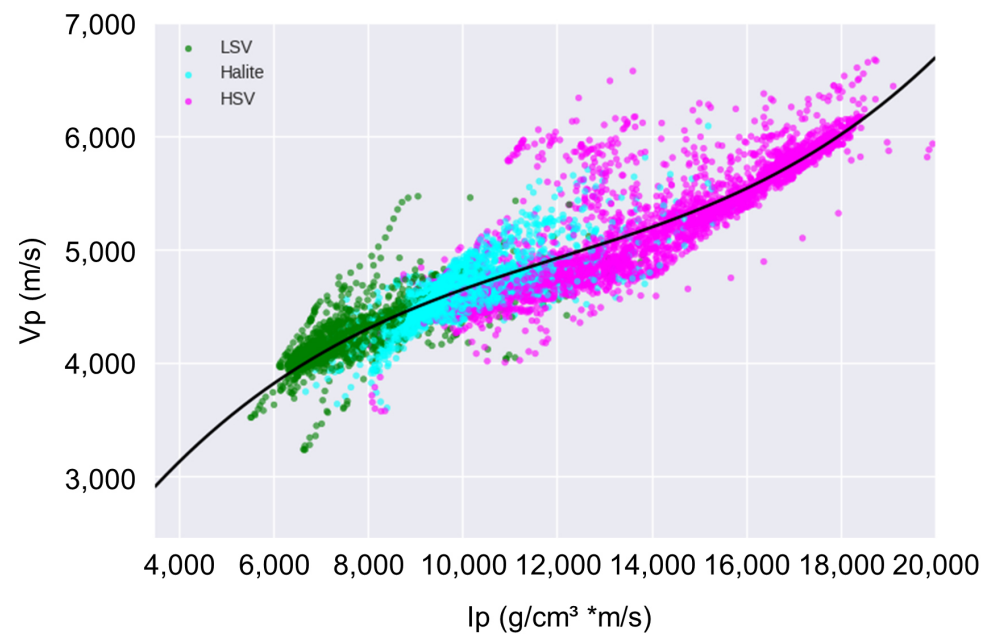

Figure 8 - Transformation from Acoustic Impedance (Ip) to Compressional Velocity (Vp). Well-log cross-plot (Vp versus Ip). Colors are mineral groups (Green - LVS; Light Blue - Halite and Purple HVS). Black line is the polynomial fit considered in Maul et al., 2019b.

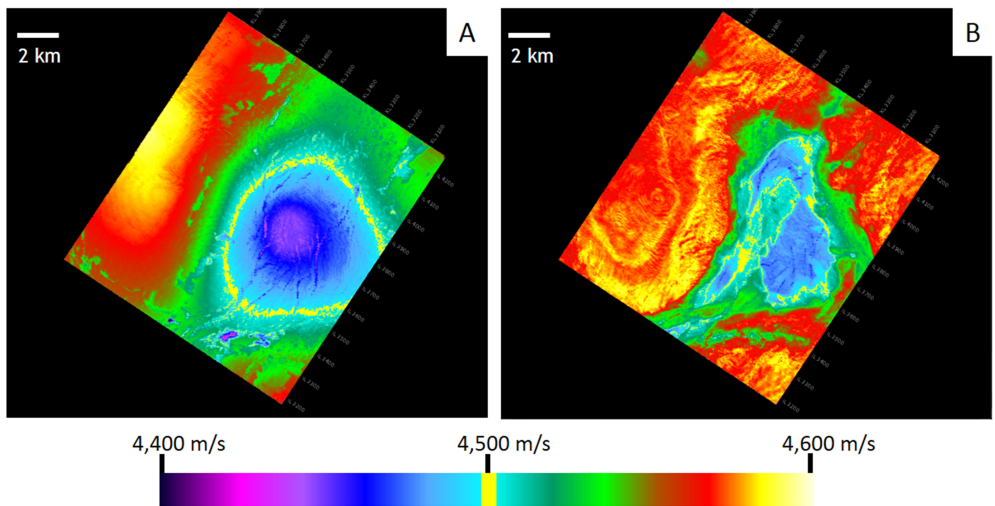

Figure 9 - Average compressional velocity (Vp) map for the evaporitic section. A: Considering the almost constant $V p(4,500 \mathrm{~m} / \mathrm{s})$ as the initial model, plus the three tomographic inversion updates for the evaporitic section; B: Considering the stratified velocity model as the initial model, plus the one tomographic inversion update for the evaporitic section. Adapted from Maul et al. (2018a).

using the combination of rock-physics analysis and model-based acoustic inversion. Remarkably, only one tomographic iteration was necessary to achieve a similar level of gather alignment.

The stratification insertion imposes to the evaporitic compressional velocity model the heterogeneities observed in the seismic response (the reflections inside the evaporitic section), and sampled during the well drilling process. Therefore, the average compressional velocity map must reflect it, which we can observe only on Figure 9B. Figure 9A does not present these heterogeneities, since it considers a smooth compressional velocity model for the evaporitic section.
Figure 10 presents a seismic section and an example of gather alignment. The main difference when adopting the stratified model is the reduction in the number of iterations necessary during the tomographic inversion. The "cost" reduction due to the application of this procedure also ensures a good image quality.

We can see through the analysis of Figures 11, 12 and 13 that, besides the gain related to the reduction of computational cost, the image quality has also improved, with better images focusing, structural representation, and vertical positioning. In these images, the only difference is the velocity model used 

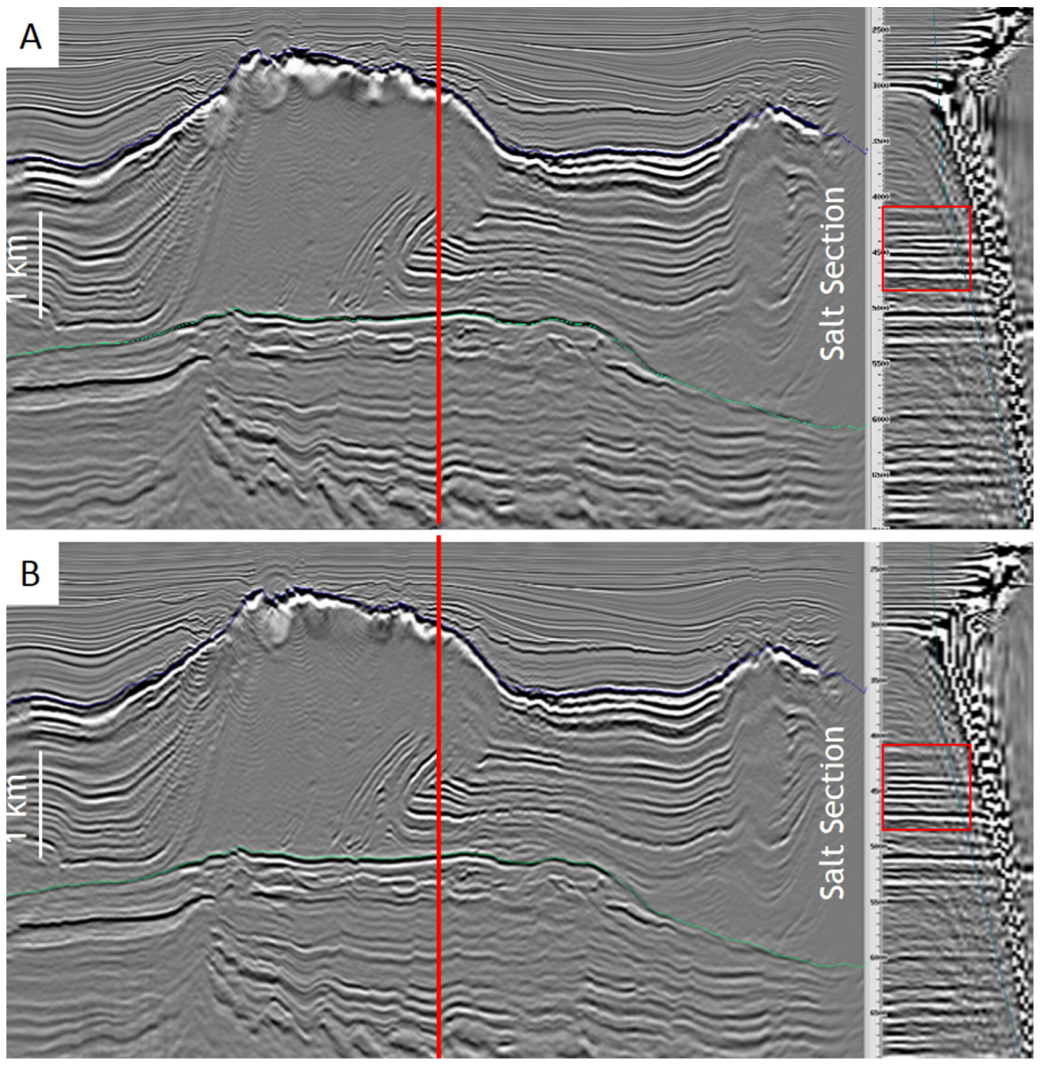

Figure 10 - Migrated seismic section and a piece of a seismic gather panel illustrating the obtained alignment considering (the vertical red lines in the left part of figures "A" and "B" represent the position where the gathers were analyzed and the boxes in the right part represent the details of the gather alignment in both cases): A: The starting compressional velocity model, almost constant, after the three tomographic inversion iterations to align the analyzed gathers; $\mathrm{B}$ : The starting compressional velocity model delivered by the stratification insertion, after the single tomographic inversion iteration to align the analyzed gathers. Observe the same level of gather alignment in both examples, which implies a reduction of computational cost when considering the stratified model. Adapted from Maul et al. (2018a).

for migration. Another point to be considered is the fact that due to computational limitations, the Kirchhoff algorithm was the choice for the seismic migration, although we are aware of better algorithms to be applied in this dataset, like Reverse Time Migration (RTM) and Least Square Migration (LSM). In other words, we believe that the image quality could be even more enhanced when considering more appropriate algorithms.

\section{CONCLUSIONS}

We believe that the way to improve seismic images in structurally complex areas such as the pre-salt reservoirs in the Santos Basin is to choose wisely the correct migration algorithm and to construct more realistic compressional velocity model containing reliable geology features.

The combination of rock-physics and model-based acoustic inversion approach gives to the evaporitic section an important contribution in terms of geology by inserting the existing multilayered stratifications.

The representation of geological features decreases the computational effort as it reduces the numbers of iterations in order to obtain good gather alignments prior to the final migration process (Maul et al., 2018a).

Besides the decrease in computational effort, the most important result when applying this combined approach (to perform the velocity update over the stratified model plus a good migration algorithm) is a more confident seismic image, 

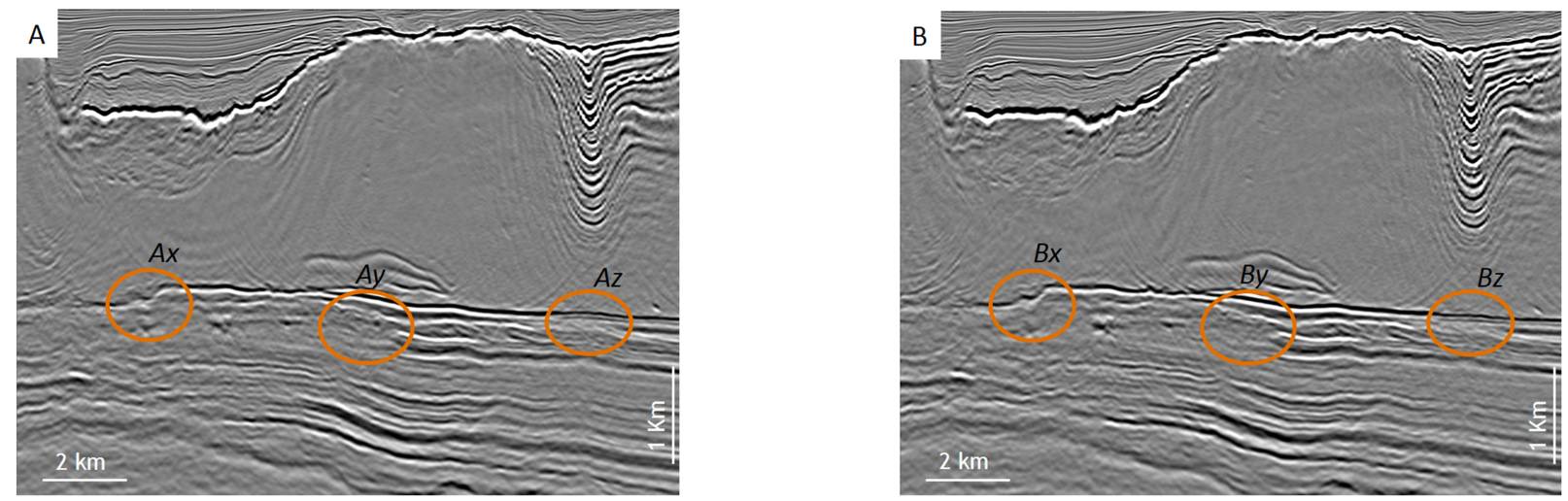

Figure 11 - Migrated seismic sections using both models: A: The starting compressional velocity model, almost constant, after the three tomographic inversion iterations to align the analyzed gathers; $B$ : The starting compressional velocity model delivered by the stratification insertion, after the one tomographic inversion iteration to align the analyzed gathers. Observe the better imaging when using the model with the stratification insertion: better continuity of the reflector $B x$ over $A x$ and By over Ay, and the more coherent positioning in Bz than Az (notice the evaporitic behavior above the analyzed point). Adapted from Maul et al. (2018a).
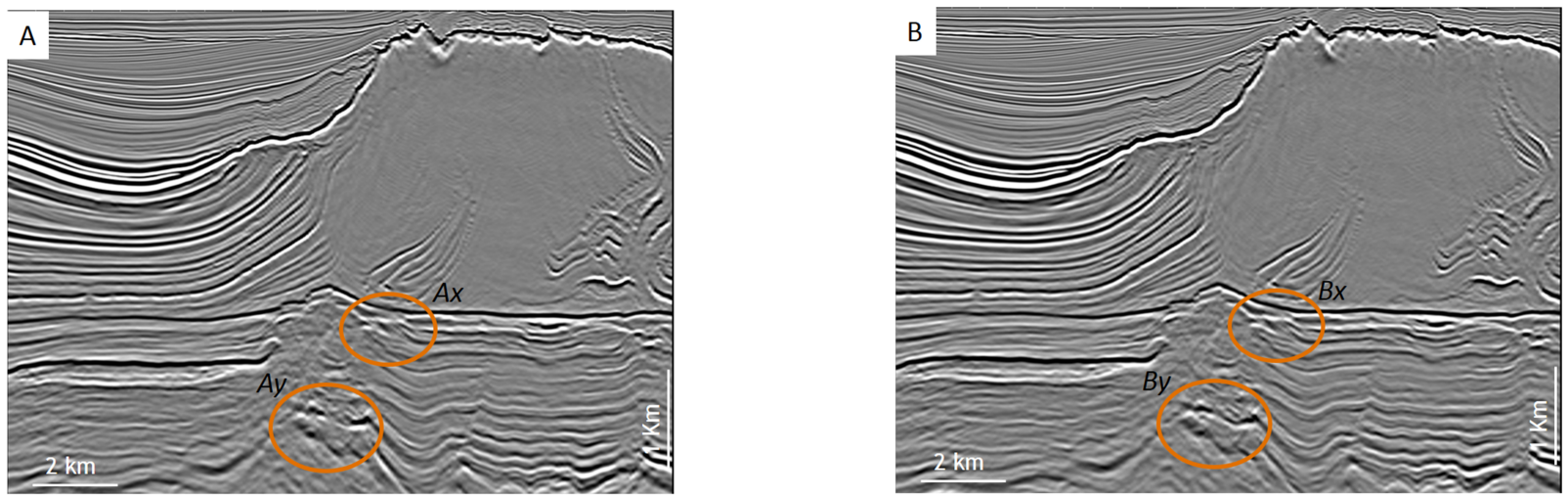

Figure 12 - Migrated seismic sections using both models: A: The starting compressional velocity model, almost constant, after the three tomographic inversion iterations to align the analyzed gathers; B: The starting compressional velocity model delivered by the stratification insertion, after the one tomographic inversion iteration to align the analyzed gathers. Observe the better focusing of the image when using the model with the stratification insertion: positions Bx over Ax, and better imaging building (continuity in geology) in By than Ay. Adapted from Maul et al. (2018a).
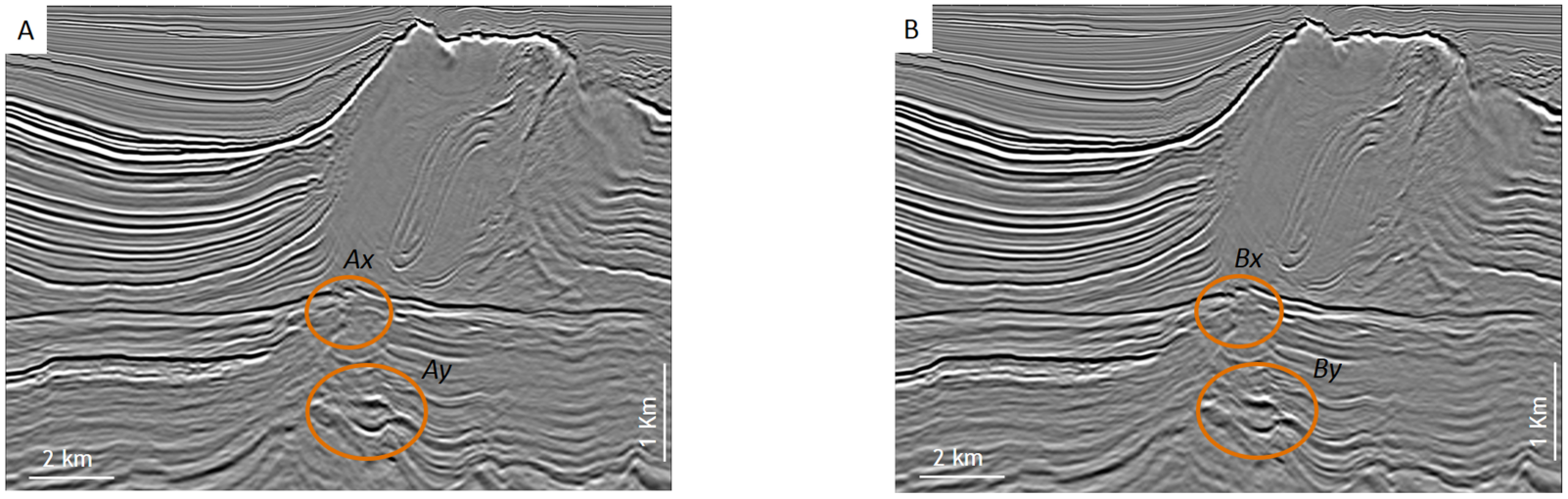

Figure 13 - Migrated seismic sections using both models: A: The starting compressional velocity model, almost constant, after the three tomographic inversion iterations to align the analyzed gathers; $B$ : The starting compressional velocity model delivered by the stratification insertion, after the one tomographic inversion iteration to align the analyzed gathers. Observe the better imaging (the fault sharping) when using the model with the stratification insertion: positions Bx over Ax, and better event focusing when comparing By over Ay. Adapted from Maul et al. (2018a). 
which covers several aspects: better representation of structures, geological event continuity, depth predictions and signal quality, allowing a better rock property distribution based on the seismic quantitative interpretation.

We still believe that the anisotropy of the evaporitic section could also consider the stratified model to guide the distribution of the three-dimension anisotropic parameters.

The methodology was tested in several seismic processing projects. Moreover, we also tested those models for new seismic design studies such as illumination studies (Maul et al., 2015), uncertainty analysis regarding both depth and lateral positioning and accuracy in reservoir property distribution (Meneguim et al., 2015; Paes et al., 2019), security in well drilling (Teixeira et al., 2015), geomechanical flow simulation (Teixeira et al., 2018).

Therefore, despite the seismic ambiguity and seismic resolution, we believe that it is an approach to consider in all projects for the pre-salt section in any basin around the world.

It is also important to take care about other relevant aspects in terms of compressional velocity model building not only for the evaporitic section as described in this paper. The authors are also researching and applying similar methodologies, looking for the incorporation of other important geologic features such as the Albian rafts in the Santos and Campos Basins, Brazilian offshore, structural complexity related to folds and faults, among others.

\section{ACKNOWLEDGMENTS}

The authors would like to express their gratitude to the Agência Nacional do Petróleo, Gás Natural e Biocombustívies (ANP) for authorization to use the data necessary for the development of this project, and for allowing the publication of the obtained results so far in the first author's doctoral research. The authors also thank Petrobras S.A. for all the financial support and availability of time and equipment for this study, as well as the colleagues who have been collaborating with this research.

\section{REFERENCES}

AMARAL PJ, MAUL A, FALCÃO L, GONZÁLEZ M \& GONZÁLEZ G. 2015. Estudo Estatístico da Velocidade dos Sais na Camada Evaporítica na Bacia de Santos. In: 14th International Congress of the Brazilian Geophysical Society. Rio de Janeiro, RJ, Brazil: SBGf. doi: 10.1190/sbgf2015-131.

BACKUS GE. 1962. Long-wave elastic anisotropy produced by horizontal layering. Journal of Geophysical Research, 67: 4427-444427-4440. doi: 10.1029/jz067i011p04427.
BARNES C \& CHARARA M. 2009. The Domain of Applicability of Acoustic Full-Waveform Inversion for Marine Seismic Data. Geophysics, 74(6): WCC91-WCC103. doi: 10.1190/1.3250269.

BARROS P, FONSECA J, TEIXEIRA L, MAUL A, YAMAMOTO T, MENEGUIM T, QUEIROZ LE, TORÍBIO T, MARTINI A, GOBATTO F \& GONZÁLEZ M. 2017. Salt Heterogeneities Characterization in Pre-Salt Santos Basin Fields. In: Offshore Technology Conference. Rio de Janeiro, RJ, Brazil: OTC. doi: 10.4043/28147-MS.

BEN-HADJ-ALI H, OPERTO S \& VIRIEUX J. 2008. Velocity Model Building by 3D Frequency-Domain, Full-Waveform Inversion of Wide-Aperture Seismic Data. Geophysics, 73(5): VE101-VE117. doi: 10.1190/1.2957948

COGAN M, ZDRAVEVA 0, KAIRZHANOVA T \& SCHOEMANN M. 2011. A Wide Azimuth TTI Model Building and Imaging Case Study from the Central Gulf of Mexico. In: 81st Annual Meeting. San Antonio, TX, USA. SEG - Society of Exploration Geophysicist. doi: 10.1190/1.3628053.

COOKE A, LE DIAGON F, DE MARCO R, AMAZONAS D, BUNTING T, MOLDOVEANU N, KLUG S \& MATTOS E. 2012. Full-Azimuth Towed-Streamer Seismic: An Exploration Tool for Pre-Salt Hydrocarbon Exploration Offshore Brazil. In: 82nd Annual Meeting. Expanded Abstracts. San Antonio, TX, USA. SEG - Society of Exploration Geophysicist. doi: 10.1190/segam2012-1076.1.

DIAS BP, BULCÃO A, SOARES FILHO DM, SANTOS LA, DIAS RM, LOUREIRO FP \& DUARTE FS. 2017. Least-Squares Migration in the Image Domain with Sparsity Constraints: An Approach for Super-Resolution in Depth Imaging. In: 15th International Congress of the Brazilian Geophysical Society. Expanded Abstracts. Rio de Janeiro, RJ, Brazil: SBGf. doi: 10.1190/sbgf2017-236.

DIAS BP, GUERRA C, BULCÃO A \& DIAS RM. 2018. Exploring Inversion Strategies in Image Domain Least Squares Migration. In: First EAGE/SBGf Workshop on Least Squares Migration. Rio de Janeiro, RJ. Brazil. LMSTU01. doi: 10.3997/2214-4609.201803060.

DIAS R, FONSECA J, BULCÃO A, DIAS B, TEIXEIRA LM, MAUL A \& BORGES F. 2019. Salt Stratification and Least Square Migration to Improve Pre-Salt Images: Santos Basin, Brazilian Offshore Example. In: 2nd EAGE/PESGB Workshop on Velocities. London, United Kingdom. doi: 10.3997/2214-4609.201900051.

FALCÃO LF. 2017. 0 Sal Estratificado e sua Importância na Modelagem de Velocidades para Fins de Migração Sísmica. Master Dissertation. Universidade Federal Fluminense, UFF. Dinâmica Oceânica e Costeira. Niterói, RJ, Brazil. 91 pp.

FONSECA J, GOBATTO F, BOECHAT J, MAUL A, YAMAMOTO T, BORN E, TEIXEIRA L \& GONZÁLEZ M. 2017. Dealing with Evaporitic Salts Section in Santos Basin during Geological Seismic Velocity Construction. In: 15th International Congress of the Brazilian 
Geophysical Society. Expanded Abstracts. Rio de Janeiro, RJ, Brazil: SBGf. doi: 10.1190/sbgf2017-350.

FONSECA J, TEIXEIRA L, MAUL A, BARROS P, BOECHAT J \& GONZÁLEZ M. 2018. Modelling Geological Layers into new Velocity Models for Seismic Migration Process: A Brazilian Pre-Salt Case. In: First EAGE/PESGB Workshop on Velocities. London, United Kingdom. doi: 10.3997/2214-4609.201800010.

GOBATTO F, MAUL A, TEIXEIRA L, GONZÁLEZ G, FALCÃO L, GONZÁLEZ $M$ \& BOECHAT JT. 2016. Refining Velocity Model within the Salt Section in Santos Basin: An Innovative Workflow to Include the Existing Stratification and its Considerations. In: 87th Annual Meeting. Dallas, TX, USA. SEG - Society of Exploration Geophysicist. doi: 10.1190/segam2016-13685489.1.

GONZÁLEZ M, GOBATTO F, MAUL A, FALCÃO L, GONZÁLEZ G, OLIVEIRA L, MENEGUIM T \& AMARAL P. 2016. Proposed Workflow to Incorporate Stratification within Salt Section using Velocity and Seismic Attributes. In: Third EAGE/SBGf Workshop on Quantitative Seismic Interpretation of Lacustrine Carbonates. Expanded Abstracts. Rio de Janeiro, RJ, Brazil. EAGE/SBGf. doi: 10.3997/22144609.201600050.

GUO N \& FAGIN S. 2002. Becoming Effective Velocity-Model Builders and Depth Imagers, Part 2 - The Basics of Velocity-Model Building, Examples and Discussions. The Leading Edge, 21(12): 1210-1216.

HU J, SCHUSTER GT \& VALASEK PA. 2001. Poststack Migration Deconvolution. Geophysics, 66(3): 939-952. doi: 10.1190/1.1444984.

HUANG Y, LIN D, BAI B, ROBY S \& RICARDEZ C. 2010. Challenges in Pre-Salt Depth Imaging of the Deepwater Santos Basin, Brazil. The Leading Edge, 29(7): 820-825. doi: 10.1190/1.3462785.

JACKSON CA-L, JACKSON MPA, HUDEC MR \& RODRIGUEZ CR. 2015. Enigmatic Structures within Salt Walls of Santos Basin - Part 1: Geometry and Kinematics from 3D Seismic Reflection and Well Data. Journal of Structural Geology, 75: 135-162. doi: 10.1016/j.jsg.2015.01.010.

JARDIM F, MAUL A, FALCÃO L \& GONZÁLEZ G. 2015. Estimating Amplitude Uncertainties through Illumination Studies for a Pre-Salt Reservoir. In: 14th International Congress of the Brazilian Geophysical Society. Expanded Abstracts. Rio de Janeiro, RJ, Brazil: SBGf. doi: 10.1190/sbgf2015-160.

JI S, HUANG T, FU K \& LI Z. 2011. Dirty Salt Velocity Inversion: The Road to a Clearer Subsalt Image. Geophysics, 76(5): WB169-WB174. doi: 10.1190/GE02010-0392.1.

JONES IF \& DAVISON I. 2014. Seismic Imaging in and around Salt Bodies. Interpretation, 2(4): SL1-SL20. doi: 10.1190/INT-2014-0033.1.

LANDRØ M, PUIGDEFABREGAS C \& ARNTSEN B. 2011. Anisotropy in the Salt Outcrop at Cardona, Catalonia - Implications for Seismic Imaging. First Break, 29: 41-45. doi: 10.3997/1365-2397.2011022.
MAUL A, JARDIM F, FALCÃO L \& GONZÁLEZ G. 2015. Observing Amplitude Uncertainties for a Pre-Salt Reservoir using Illumination Study (Hit-Maps). In: 77th EAGE Conference \& Exhibition. Madrid, Spain. doi: 10.3997/2214-4609.201412921.

MAUL A, FONSECA J, TEIXEIRA L, BARROS P, BOECHAT JB, NUNES JP, YAMAMOTO T, GONZÁLEZ M \& GONZÁLEZ G. 2018a. Modeling Intra-Salt Layers when Building Velocity Models for Depth Migration. Examples of the Santos Basins, Brazilian Offshore. In: 88th Annual Meeting. Anaheim, CA, USA. SEG - Society of Exploration Geophysicist. doi: 10.1190/segam2018-2996209.1.

MAUL AR, SANTOS MAC \& SILVA CG. 2018b. Few Considerations, Warnings and Benefits for the E\&P Industry when Incorporating Stratifications inside Salt Sections. Brazilian Journal of Geophysics, 36(4): 461-477. doi: 10.22564/rbgf.v36i4.1981.

MAUL AR, SANTOS MAC \& SILVA CG. 2018c. Evaporitic Section Characterization and its Impact over the Pre-Salt Reservoirs, Examples in Santos Basin, Offshore. In: Rio Oil \& Gas Exposition and Conference. Rio de Janeiro, RJ, Brazil: IBP.

MAUL AR, SANTOS MAC, SILVA CG, FONSECA JS, GONZÁLEZ MLAF, TEIXEIRA LMS, YAMAMOTO TM, BORGES FAS \& PONTES RLB. 2019a. Geological Characterization of Evaporitic Sections and its Impacts on Seismic Images: Santos Basin, Offshore Brazil. Brazilian Journal of Geophysics, 37(1): 55-68. doi: 10.22564/rbgf.v37i1.1989.

MAUL AR, SANTOS MAC, SILVA CG, GONZÁLEZ MLAF, FONSECA JS, BORGES FAS \& ABREU CEBS. 2019b. Evaporitic Velocity Modeling Uncertainties and Variabilities: Implication for Pre-Salt Projects in the Santos Basin, Brazil. Brazilian Journal of Geophysics, 37(2): 175-186. doi: 10.22564/rbgf.v37i2.2003.

MENEGUIM T, MENDES SC, MAUL A, FALCÃO L, GONZÁLEZ M \& GONZÁLEZ G. 2015. Combining Seismic Facies Analysis and Well Information to Guide new Interval Velocity Models for a Pre-Salt Study, Santos Basin, Brazil. In: 14th International Congress of the Brazilian Geophysical Society. Rio de Janeiro, RJ, Brazil: SBGf. doi: 10.1190/sbgf2015-271.

MOHRIAK W, NEMCOK M \& ENCISO G. 2008. South Atlantic Divergent Margin Evolution: Rift-Border Uplift and Salt Tectonics in the Basins of SE Brazil. Geological Society, London, UK. Special Publications, 294(1): 365-398.

NEMETH T, WU C \& SCHUSTER GT. 1999. Least-Squares Migration of Incomplete Reflection Data. Geophysics, 64: 208-221. doi: 10.1190/1.1444517.

OPERTO S, GHOLAMI Y, PRIEUX V, RIBODETTI A, BROSSIER R, METIVIER L \& VIRIEUX J. 2013. A Guided Tour of Multiparameter Full-Waveform Inversion with Multicomponent Data: From Theory to Practice. The Leading Edge, 32: 1040-1054. doi: 10.1190/tle32091040.1. 
PAES M, PEREIRA CE, PINTO V, MAUL A, GONZÁLEZ M, MENEGUIM T, GONZÁLEZ G, MEYER R \& FURLAND L. 2019. Brazilian Pre-Salt Gross-Rock Volume Uncertainties: Integration between Velocity Model and Seismic Resolution. In: 81st EAGE 2019. Conference and Exhibition. London, UK. doi: 10.3997/2214-4609.201901460.

RAYMER DG, KENDALL JM, BEAUDOIN MC, MUELLER MC \& KENDALL RR. 1999. Measuring the Anisotropy of Salt in the Mahogany Oil Field, Gulf of Mexico. In: AAPG International Conference and Exhibition. Birmingham, England. p. 100-103.

RAYMER DG, TOMASSI A \& KENDALL JM. 2000. Predicting the Seismic Implications of Salt Anisotropy using Numerical Simulations of Halite Deformation. Geophysics, 65: 1272-1280. doi: 10.1190/1.1444818.

TEIXEIRA L, GOBATTO F, MAUL A, CRUZ N, GONÇALVES C \& LAQUINI J. 2017. Rock Physics and Seismic Inversion to Identify Stratification within Salt Section Supporting Velocity, Facies Modeling and Geomechanical Analysis. In: 15th International Congress of the Brazilian Geophysical Society. Expanded Abstracts. Rio de Janeiro, RJ, Brazil: SBGf. doi: 10.1190/sbgf2017-002.

TEIXEIRA L, NUNES JP, FONSECA J, MAUL A, BARROS P \& BORGES F. 2018. Seismic-Based Salt Characterization for Geomechanical Modelling of a Pre-Salt Reservoir. In: 80th EAGE Conference \& Exhibition. Copenhagen, Denmark. doi: 10.3997/2214-4609.20180131.

TEIXEIRA L \& LUPINACCI W. 2019. Elastic Properties of Salt in the Santos Basin: Relations and Spatial Predictions. Journal of Petroleum Science and Engineering, 180: 215-230. doi: 10.1016/j.petrol.2019.05.024.

TORÍBIO T, QUEIROZ LE, TEIXEIRA L, YAMAMOTO T, MENEGUIM T, LEONARDI 0, CORTEZ M, RELVAS MT., MOLITERNO AM, TARTARINI
A, FONSECA J \& MAUL A. 2017. Characterizing Evaporitic Section and Geomechanical Properties using Seismic Inversion, a Case Study for Santos Basin. In: 15th International Congress of the Brazilian Geophysical Society. Expanded Abstracts. Rio de Janeiro, RJ, Brazil: SBGf. doi: 10.1190/sbgf2017-226.

VIGH D, JIAO K, WATTS D \& SUN D. 2014. Elastic Full-Waveform Inversion Application using Multicomponent Measurements of Seismic Data Collection. Geophysics, 79(2): R63-R77. doi: 10.1190/ge02013-0055.1.

VIGH D \& STARR EW. 2008. 3D Prestack Plane-wave, Full-waveform Inversion. Geophysics, 73(5): VE135-VE144. doi: 10.1190/1.2952623.

VIGH D, STARR EW \& DINGWALL K. 2009. 3D Prestack Full Waveform Inversion. In: Offshore Technology Conference. Houston, TX, USA (OTC 19897). doi: 10.4043/0TC-19897-MS.

WANG P, HUANG H \& WANG M. 2017. Improved Subsalt Images with Least-Squares Reserve Time Migration. Interpretation, 5(3): SN25-SN32. doi: 10.1190/INT-2016-0203.1.

YAN F, HUA H, YAO Q \& CHEN XL. 2016. Seismic Velocities of Halite Salt: Anisotropy, Heterogeneity, Dispersion, Temperature, and Pressure Effects. Geophysics, 81(4): D293-D301. doi: 10/1190/ge02015-0476.1.

ZDRAVEVA O, WOODWARD M, NICHOLS D \& OSYPOV $K$. 2011. Building Anisotropic Models for Depth Imaging: comparing different approaches. In: 12th International Congress of the Brazilian Geophysical Society. Society of Exploration Geophysicists and Brazilian Geophysical Society, Expanded Abstracts. Rio de Janeiro, Brazil. doi: 10.4043/22827-MS. 